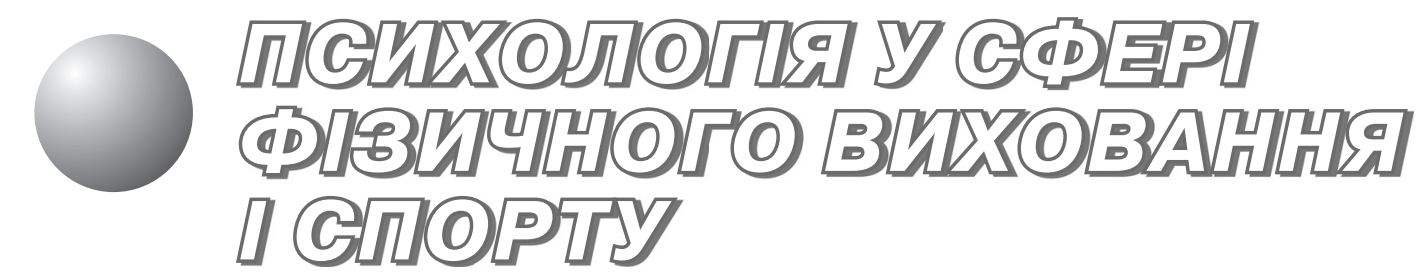

\title{
Визначення показників домінуючої мотивації у осіб молодого віку, які займаються фітнесом за типовими фітнес-програмами
}

\author{
С. М. Іващенко
}

Національний університет фізичного виховання і спорту України, Київ, Україна

\begin{abstract}
Резюме. Приведены результаты исследования показателей доминирующей мотивации у студентов Национального университета физического воспитания и спорта Украины, которые занимаются фитнесом в фитнес-клубах города Киева с использованием типичных программ. При этом была применена разработанная нами анкета, в которой указывались основной и дополнительные мотивы стремления студентов к достижению хорошей физической формы и улучшению самочувствия. Установлено, что у молодых людей, которые систематически занимаются фитнесом, прослеживается связь между показателями мотивации к достижению успеха и показателями самочувствия в ходе тренировочного процесса.
\end{abstract}

Ключевые слова: доминирующий мотив, фитнес-программа, специальная тестовая анкета, степень физической подготовленности, показатель самочувствия.

Summary. This article presents the results of a study of indicators dominant motivation of the students of National University of Physical Training and Sports of Ukraine, who are engaged in fitness trainings in fitness clubs in the city of Kiev with typical programs. At the same time was used for this experiment developed a questionnaire, which indicated the main and additional reasons for the desire of students to achieve physical fitness and better health. It was found that young people who regularly engage in fitness, a correlation between indices of motivation to achieve success and indicators of well-being during the training process.

Key words: dominant motivation, fitness program, a special test profile, the degree of physical fitness, indicator of health.

Постановка проблеми. Однією з найбільш важливих обставин життєдіяльності людей у більшості країн світу $€$ необхідність їх невпинної боротьби за збереження здоров'я в умовах поступового погіршення екологічної ситуації та постійної дії численних стресових фракторів [14].

Щорічно збільшується кількість осіб, які дійшли висновку про те, що вирішити проблему збереження ресурсу здоров'я та підвищення якості життя можливо лише за умов здорового способу життя, відмови від шкідливих звичок та систематичних занять фрізичними вправами $[3,7]$. Саме цим пояснюється тенденція до збільшення кількості осіб, які систематично відвідують дер- жавні та приватні тренажерні комплекси з метою підвищення шляхом фрізичних тренувань індивідуального рівня фрізичного розвитку, підтримки опірності організму до дії несприятливих фракторів та покращення самопочуття і настрою $[5,9$, 12, 15].

Результати наукових досліджень, проведених 3 метою вивчення закономірностей впливу на організм людини навантажень, пов'язаних з тренувальним процесом в межах різних видів спорту, представлені в багатьох вітчизняних і закордонних наукових працях $[8,10]$. Деякі роботи були присвячені питанням дослідження особливостей процесу розвитку характерних органічних змін 
у стані тканин спортсменів, що виникають внаслідок дії тривалих та інтенсивних фрізичних навантажень у ході тренувального процесу $[1,6]$.

Але, на жаль, до цього часу залишається ще недостатньо вивченим питання дослідження закономірностей змін показників мотиваційної спрямованості осіб молодого віку в процесі їх зайняття фрітнесом із використанням стандартних фрітнес-програм.

Мета дослідження - визначення характеру і рівня домінуючої мотивації до занять фрітнесом з використанням типових фрітнес-програм серед молодих осіб віком від 17 до 25 років.

Методи та організація дослідження. Вивчення показників домінуючої мотивації до занять фітнесом проводили серед студентів Національного університету фрізичного виховання і спорту України в період з 15 лютого по 28 квітня 2010 р. У дослідженні взяли участь 92 особи віком від 17 до 25 років (24 чоловіки та 68 жінок).

3 метою отримання об'єктивних даних щодо показників домінуючої мотивації застосовували анкетно-опитувальний метод 3 використанням розроблених спеціально для даного дослідження анкет, де позначалися паспортні дані, основні антропометричні параметри досліджуваних, відомості про загальну тривалість і алгоритм їх тренувань, головний і додаткові спонукальні мотиви та показники самопочуття і фрізичного стану в ході тренувального процесу.

Показники самопочуття оцінювали за допомогою ергономічної методики самоконтролю спеціалістів, діяльність яких пов'язана з фрізичними навантаженнями [2]. Цю методику можна вважати сучасним варіантом методики САН (самопочуття, активність, настрій), адаптованим до умов професійної діяльності визначеного контингенту спеціалістів. У випадках, коли у досліджуваних скарги на стан здоров'я були повністю відсутні, їх самопочуття оцінювали в 5 балів. За наявності незначних скарг, що не знижували спроможності до виконання тренувальних вправ, виставляли оцінку в 4 бали. Коли погіршення самопочуття несуттєво впливало на спроможність до виконання тренувальних завдань, досліджувані отримували 3 бали. При помірному зниженні спроможності до виконання стандартних тренувальних навантажень виставляли 2 бали. Якщо здатність досліджуваних до виконання стандартного комплексу вправ знижувалася суттєво, вони отримували оцінку в 1 бал.

Нарешті, у випадку повної неспроможності досліджуваних до проведення тренування, вони зовсім не отримували балів.
Аналіз отриманих у ході дослідження даних виконували за допомогою стандартних програм статистичного аналізу Microsoft Office Excel 2000 і пакета прикладних статистичних програм "Statistica" [11, 13].

Результати дослідження та їх обговорення. Враховуючи те, що в межах вікового діапазону від 17 до 25 років рівень мотиваційної спрямованості може суттєво змінюватись, було виконано розподіл учасників дослідження на три більш вузькі додаткові вікові групи:

- від 17 до 19 років;

- від 20 до 22 років;

- від 23 до 25 років.

Результати розподілу учасників дослідження на відповідні групи представлено в таблиці 1.

3 метою визначення рівня мотиваційної спрямованості досліджуваних на досягнення успіху та уникнення невдач у процесі занять фрітнесом, було використано анкетний тест Т. Елерса, розроблений на базі результатів фундаментальних досліджень Х. Хекхаузена та Д. Аткінсона [4].

Враховуючи те, що будь-який мотив $€$ спонуканням до того чи іншого виду активної діяльності або до задоволення потреб визначеним шляхом, у ході даного дослідження було проведено аналіз характеру і змісту основних і додаткових спонукальних мотивів у тих студентів, що протягом усього періоду спостереження тричі на тиждень займалися фрітнесом у тренажерних залах різних районів міста Києва. За результатами дослідження, у $76 \%$ випадків загальна мотиваційна спрямованість учасників тренувань визначалася наявністю кількох спонукальних мотивів, один з яких визнавався основним. У $84 \%$ випадків основним фактором, яким визначалася домінуюча мотивація досліджуваних, було їх прагнення до підтримки належної фрізичної форми, збереження оптимального режиму рухової активності та досягнення ефекту покращення самопочуття і настрою.

Проведення етапу дослідження, метою якого було визначення рівня спонукального напруження у представників усіх спеціальних груп дослід-

ТАБЛИЦЯ 1 - Розподіл учасників дослідження на спеціальні групи за показниками статі і віку

\begin{tabular}{|l|c|c|c|}
\hline Вік, років & Чоловіки & Жінки & Всього \\
\hline $17-19$ & 2 особи & 5 осіб & 7 осіб \\
& $(2,3 \%)$ & $(5,4 \%)$ & $(7,7 \%)$ \\
\hline $20-22$ & 15 осіб & 36 осіб & 51 особа \\
& $(16,3 \%)$ & $(39,1 \%)$ & $(55,4 \%)$ \\
\hline $23-25$ & 7 осіб & 27 осіб & 34 особи \\
& $(7,7 \%)$ & $(29,2 \%)$ & $(36,9 \%)$ \\
\hline$\Sigma$ & 24 особи & 68 осіб & 92 особи \\
& $(26,1 \%)$ & $(73,9 \%)$ & $(100 \%)$ \\
\hline
\end{tabular}


жуваних за домінуючою мотивацією до вдосконалення фрізичної форми, підтримки оптимального режиму рухової активності та покращення самопочуття, забезпечило можливість отримання відповідних результатів розподілу його показників між описаними вище категоріями учасників (табл. 2).

Дані, наведені в таблиці 2, свідчать про те, що мотивація досліджуваних до досягнення успіху відповідає середньому і помірно високому рівням.

Крім того, порівняння показників рівня домінуючої мотивації в різних вікових групах дозволяє встановити тенденції їх змін у процесі збільшення віку досліджуваних. Так, наприклад, у групі жінок віком від 17 до 19 років рівень домінуючої мотивації становив 16,4 бала, у групі віком від 20 до 22 років - 19,1 бала і у групі віком від 23 до 25 років - 19,5 бала.

Таким чином, зі збільшенням віку жінок рівень домінуючої мотивації до досягнення успіху шляхом систематичних занять фрітнесом у тренажерних залах поступово зростає. На відміну від цього, у групах чоловіків рівень домінуючої мотивації при переході від вікового діапазону від 17 до 19 років до діапазону від 20 до 22 років зростає від 12,6 до 17,2 бала, а при переході від групи віком від 20 до 22 років до групи віком від 23 до 25 років цей рівень знижується від 17,2 до 14,8 бала.

Результати аналізу даних підтвердили фракт існування зв'язку між показниками мотивації учасників дослідження до досягнення успіху в тренуваннях та значеннями інтегрального індексу оцінки їхнього самопочуття (див. табл. 2).

Слід зазначити, що незважаючи на безумовне домінування мотиву прагнення до підтримки належної фрізичної форми, збереження оптимального режиму рухової активності та досягнення ефректу покращення самопочуття і настрою, у більшості учасників дослідження мали місце й інші мотиви, які вважалися додатковими.

Серед цих мотивів доцільно відмітити такі:

- підвищення натренованості та оптимізація функціонального стану серцево-судинної системи $(12,4 \%)$;

- досягнення позитивного впливу на опорноруховий апарат з метою покращення статури або зменшення больового синдрому (23,7 \%);

- зниження маси тіла (26,5 \%);

- корекція фрігури (14,3 \%);
- антистресовий еорект тренувального процесу $(10,8 \%)$;

- інші додаткові мотиви (12,3\%).

Для отримання більш повної інформації та оцінки всього комплексу фракторів мотивації у осіб молодого віку, які займаються фрітнесом, слід застосовувати методику інтегральної оцінки домінуючого та додаткових спонукальних мотивів, а також визначати динаміку змін їх показників у ході тренувального процесу.

\section{Висновки:}

1. Загальний рівень мотиваційної спрямованості осіб, які систематично займаються фрітнесом, залежить від параметрів їх домінуючого та додаткових спонукальних мотивів (від 12,6 \pm 0,6 до $19,5 \pm 1,3)$.

2. Існує прямий зв'язок між значеннями показників мотивації до досягнення успіху у осіб молодого віку, котрі займаються фрітнесом, та значеннями показників оцінки їх самопочуття в ході тренувального процесу $(p<0,1)$.

3. У жінок, що систематично займаються фрітнесом, спостерігається більш стабільна тенденція до зростання рівня мотиваційної спрямованості, на відміну від чоловіків, у яких така тенденція може мати тимчасовий характер (жінки - 16,4 \pm 0,8; 19,1 $\pm 1,2 ; 19,5 \pm 1,3$; чоловіків $-12,6 \pm 0,6 ; 17,2 \pm 0,9 ; 14,8 \pm 0,7)$.

\section{Література}

1. Бруско А. T. Механизм трофического влияния фризических нагрузок на структурно-фрункциональную организацию костей / А. Т. Бруско, В. П. Омельчук // Пробл. остеопенії. - 1998. - Т. 1, № 1. - С. $11-18$.

2. ВасильеВа О. С. Психология здорового человека / О. С. Васильева, Ф. З. Филатов. - М., 2001. - 337 с.

3. ИВаненко А. В. Формы, методы и объекты контроля за обеспечением санитарно-эпидемиологического благополучия населения / А. В. Иваненко, Е.В.Иродова // Гигиена и санитария. - 2003. - № 2. - С. 67-68.

4. ИВаноВ Ю. И. Статистическая обработка результатов медико-биологических исследований на микрокалькулято- 
рах по программам / Ю. И. Иванов, О. Н. Погорелюк. М.: Медицина, 1990. - 224 с.

5. Леъенець В. М. Синдром перевантаження. Діагностика і лікування / В. М. Левенець // Спорт. медицина. 2003. - № 1. - С. 32-36.

6. Лисицкая Т. С. Добро пожаловать в фитнес-клуб! / Т. С. Лисицкая. - М.: Изд. центр “Академия”, 2008. $102 \mathrm{c}$.

7. Поворознюк В. Особливості структурно-фрункціонального стану кісткової тканини у спортсменок, що займаються ігровими видами спорту / В. Поворознюк, Л. Шахліна, Т. Орлик, Н. Ребицька // Спорт. медицина. - 2003. № 1. - С. $37-40$.

8. Пољорознюк В. Структурно-фрункциональное состояние костной ткани у гимнасток высокой квалификации / В. Поворознюк, Л. Шахлина, А. Новохацкий // Наука в олимп. спорте. Спецвыпуск “Женщина и спорт”. - 2000. C. $108-112$.

9. Пономаренко В. М. Збереження і зміцнення здоров'я призовників і молоді - важливий напрям охорони здоров'я / В.М.Пономаренко, Т. С. Грузєва / / Військова медицина України. - 2002. - № 3. - С. 5-13.

10. Страшко С. В. Соціально-просвітницький тренінг 3 формування мотивації до здорового способу життя. Навчально-методичний посібник для студентів вищих педагогічних закладів / С. В. Страшко, Л. А. Животовська. - К.: Освіта України, 2009. - 280 с.

11. Сухарев А. Г. Особенности свободного времени и физическая работоспособность подростков / А. Г. Сухарев, В. Ф. Портновский / / Гигиена и санитария. - 1995. № $6 .-$ С. $29-31$.

12. Тестирование в спортивной медицине / [В. Л. Карпман, З. Б. Белоцерковский, И. А. Гудков]. - М.: Физкультура и спорт, 1988. - 208 с.

13. Хижняк М. І. Дослідження частоти виявлення скарг на погіршення самопочуття серед осіб молодого віку в залежності від режиму їх фрізичної активності / М.І.Хижняк, С. М. Іващенко, В. М. Якимець // Зб. наук. праць Української військово-медичної академії. - 2010. - Вип. 26. C. $28-32$.

14. Хоули Э. Т. Оздоровительный фитнес / Э. Т. Хоули, Б. Д. Френкс. - К.: Олимп. лит., 2000. - 367 с.

15. Atkinson J.W. An Introduction to Motivation / J. W. Atkinson. - New York: Van Nostrand Reinhold, 1964. $355 \mathrm{p}$.

\section{References}

1. Brusco A. T. The mechanism of trophy iinfluence of exercise on the structural and functional organization of bones
/ A. T. Brusco, V. P. Omelchuk / / Problems of osteopenia. 1998. - Vol. 1, N 1. - P. 11-18.

2. Vasilieva $O$. S. Psychology of a healthy person / O. S. Vasilieva, F. Z. Filatov. - Moscow, 2001. - 337 p.

3. Ivanenko A. V. The forms, methods and facilities oversight of sanitary-epidemiological / A. V. Ivanenko, E. V. Irodova // Hygiene and Sanitation. - 2003. - N 2. - P. 67-68.

4. Ivanov $Y$. I. Statistical analysis of the results of biomedical research in the calculator program / Y. I. Ivanov, O. N. Pogorelyuk. - Moscow: Medicine, 1990. - 224 p.

5. Levenets V. M. Overload syndrome. Diagnostic and treatment / V. M. Levenets // Sports Medicine. - 2003. N 1. - P. 32-36.

6. Lisitskaya T. S. Welcome to the fitness club! / T. S. Lisitskaya. - Moscow: Publishing center "Academy", 2008. - 102 p.

7. Povoroznyuk V. Features of structural and functional state of bone turnover in athletes involved in sports gaming / V. Povoroznyuk, L. Shahlina, T. Orlik, N. Rebitska // Sports Medicine. - 2003. - N 1. - P. 37-40.

8. Povoroznyuk V. Structural and functional state of bone tissue in female gymnasts of high skill / V. Povoroznyuk, L. Shahlina, A. Novohatsky // Science in Olympic sports. Special issue of "Women and Sport". - 2000. - P. 108-112.

9. Ponomarenko V. M. Preservation and promotion of health and recruits young people - an important direction of Health / V. M. Ponomarenko, T. S. Gruzieva // Military Medicine of Ukraine. - 2002. - N 3. - P. 5-13.

10. Strashko S. V. Socio-educational training in motivation for a healthy lifestyle. Manual for students of higher educational institutions / S. V. Strashko, L. A. Zhivotovska. - Kiev: Education of Ukraine, 2009. - 280 p.

11. Sukharev $A$. G. Features of free time and physical performance adolescents / A. G. Sukharev, V. F. Portnovsky // Hygiene and Sanitation. - 1995. - N 6. - P. 29-31.

12. Testing in sports medicine / [V. L. Karpman, Z. B. Belotserkovsky, I. A. Gudkov]. - Moscow: Physical Culture and Sports, 1988. - 208 p.

13. Khizhnyak M. I. Investigation of frequency detection complaints worsening health among young persons, depending on the mode of physical activity / M. I. Khizhnyak, S. M. Ivashchenko, V. M. Yakimets // Collected Works of Ukrainian Military Medical Academy. - 2010. - Issue. 26. P. 28-32.

14. Howley E. T. Wellness Fitness / E. T. Howley, B. D. Frenks - Kiev.: Olymp. lit., 2000. - 367 p.

15. Atkinson J. W. An Introduction to Motivation / J. W. Atkinson. - New York: Van Nostrand Reinhold, 1964. $355 \mathrm{p}$. 